\title{
Colonization record of Isognomon bicolor (Mollusca: Bivalvia) on pipeline monobuoys in the Brazilian south coast
}

\author{
Vanessa Ochi Agostini ${ }^{*}$ and Carla Penna Ozorio²
}

\begin{abstract}
Background: The introduction of alien species in a system affecting native species due to competition for food and space. The purse oyster Isognomon bicolor (Bivalvia, Pteriidae), a potential exotic invader, presents gaps in its distribution and ecology knowledge in Brazilian coast. For this reason, our objective was to investigate the occurrence of this oyster on pipeline monobuoys in Rio Grande do Sul, southern Brazil. Specimens were collected monthly during surveys carried out from March 2010 to June 2011 at the Tramandaí Beach, along two pipeline monobuoys, MN-601 and MN-602, randomly from the depths of three and $22 \mathrm{~m}$.

Results: We found I. bicolor dwelling on artificial hard substrates present in the Rio Grande do Sul coast, Brazil. This Caribbean bivalve was accidentally introduced to the Brazilian coast by ballast water from ships and, until now; it had not been recorded on the coast of Rio Grande do Sul state, which is under subtropical conditions.

Conclusions: The occurrence of I. bicolor in the faunistic surveys accomplished in the Rio Grande do Sul coast represents the first documented record for this species in this region. As this species is a potential exotic invader, with a high dispersal capacity, control measures must be employed to prevent its spread.
\end{abstract}

Keywords: Alien species, Artificial substrate, Biofouling, Bivalvia, Exotic species, Hard substrate, Pipeline, Pteriidae, Purse oyster, Tramandaí beach

\section{Introduction}

According to Rios' (2009) catalogue of mollusks of the Brazilian coast, Bivalvia is represented by a total of 391 species, with five belonging to family Pteriidae Gray, 1847. Among the South Atlantic coast species, only one, Pteria hirundo (Linnaeus, 1758), has been recorded until now from the Rio Grande do Sul (RS) state. The occurrence of purse oyster Isognomon bicolor (C. B. Adams, $1845)$ in the faunistic surveys accomplished in the Rio Grande do Sul coast represents the first documented record for this species in this region, thus increasing the number of Pteriidae in the benthic communities of the South Atlantic Ocean. Isognomon bicolor is a bivalve found in intertidal and subtidal artificial and natural hard substrates. They are seen in tide pools and other

\footnotetext{
* Correspondence: voagostini@gmail.com

${ }^{1}$ Universidade Federal do Rio Grande (FURG), Programa de Pós-Graduação em Oceanografia Biológica (PPGOB), Instituto de Oceanografia (IO), Avenida Itália, Km 8, CEP $96203-900$ Rio Grande, RS, Brazil

Full list of author information is available at the end of the article
}

marine shallow areas and, on rocky shores with high energy, occupying cracks in protected sites. This species is an exotic mollusk to Brazilian marine fauna, native to the Western Central Atlantic Coast living usually in the Caribbean region. They are often found in high densities (Domaneschi \& Martins, 2002; Santos et al. 1845) and interfere with the survival capacity of native species (Breves-Ramos et al. 2009). As there are disagreements about the identification of Isognomon species (Domaneschi \& Martins, 2002), its current distribution on the Brazilian coast is not well established. However I. bicolor can be considered an invasive organism based on population size (Martinez, 2012) and has been recorded to North, Northeast and Southwest and more recently to the South of Brazil (Domaneschi \& Martins, 2002; Loebmann et al., 2010; Martinez, 2012; Dias et al., 2013, Santos et al., 2015).

The first record of Isognomon to Brazil was made by Matthews \& Kempf (1970) with the observation of lsognomon cf. alatus in Atol das Rocas, Rio Grande do 
Norte. Nevertheless, Domaneschi \& Martins (2002) believe that the species found by these authors would likely be I. bicolor. According to Santos et al., (2015), the probable vector to introduce $I$. bicolor on the Brazilian coast is the ballast water of international cargo ships. This introduction is affecting native species due to competition for food and space (Kado, 2003) and may have a negative influence on hard substrates communities and consequently in organisms of economic interest.

I. bicolor, a potential exotic invader, with a high dispersal capacity (Martinez, 2012) presents gaps in its distribution and ecology knowledge (Breves et al., 2014), so its records in any coast are vital to promoting an efficient environmental management.

\section{Material and methods}

Isognomon bicolor specimens were collected monthly between March 2010 and June 2011, during samplings on two offshore pipeline monobuoys, MN-601 (3000'40" S; $\left.50^{\circ} 05^{\prime} 42^{\prime \prime} \mathrm{W}\right)$ and MN-602 (3001'52” S; 5004'36” W) at Tramandaí Beach, RS, Brazil. These petroleum industry artifacts belong to company TRANSPETRO (Petrobras Transportes S.A.) and have been installed for transporting of oil products (MN-601) and crude oil (MN-602). The first is located $4 \mathrm{~km}$ offshore, $20 \mathrm{~m}$ deep, and the second is $6 \mathrm{~km}$ offshore, $24 \mathrm{~m}$ deep. The connection between the tanker and monobuoys is made by $16 \mathrm{in}$. rubber pipeline, and the product transport occurs by piping to the Almirante Soares Dutra Terminal (Tedut) in Osório. In 2009, this monobuoys/pipeline system was used by 224 ships.

The sampling was performed by professional divers of the TRANSPETRO through aleatory scrapings between depths of three and $22 \mathrm{~m}$, considering both superficies, metal (vertical position) and rubber (diagonal position), depending on sea conditions. The organisms were removed of $900 \mathrm{~cm}^{2}$ for posterior identification. Then, specimens were transported to the laboratory, separated from community and identified using Domaneschi \& Martins (2002) description.

Usual measures for this bivalve were taken from each animal and digital images were taken (Fig. 1). The density was estimated, being the individuals fixed in ethyl alcohol $70 \%$ and deposited in the scientific collection of the Centro de Estudos Costeiros Limnológicos e Marinhos (CECLIMAR) at Federal University of Rio Grande do Sul (UFRGS) (30 voucher specimens).

According to Domaneschi \& Martins (2002), intraspecific variation and shell deformation due to large individuals' density in restricted areas as cavities or cracks may make it difficult to distinguish between I. alatus and $I$. bicolor. However, I. bicolor can be identified according to the redescription by the same authors.

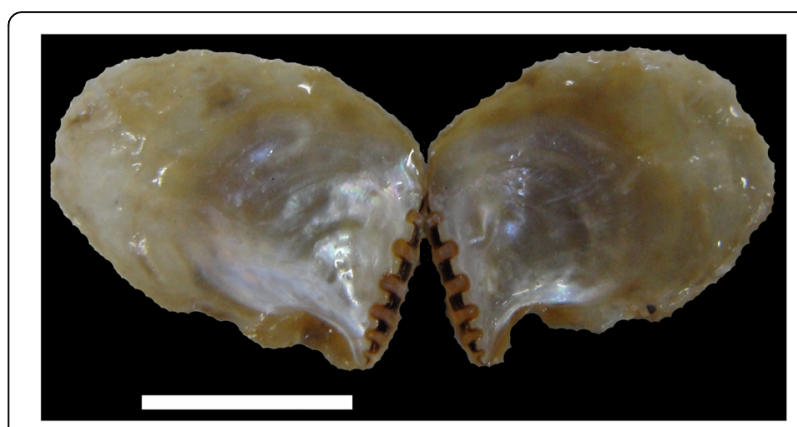

Fig. 1 Exotic species Isognomon bicolor found in pipeline

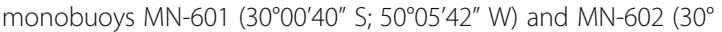
$01^{\prime} 52^{\prime \prime}$ S; 5004'36" W) at Tramandaí Beach, RS, Brazil between March 2010 and June 2011 (Scale: $10 \mathrm{~mm}$ )

I. bicolor has $(i)$ a shell with height greater than the length, the left valve slightly convex to the right; (ii) variation in color from blackened brown, slightly red, to cream-yellow tonnes or slightly greenish; (iii) outer surface ornamented with irregular, concentric and overlapped lamellae; (iv) inside the valves, the area that encloses the body is moderately concave, covered with bright nacre, the color uniformly iridescent; (v) height $(\mathrm{mm}): 1.3$ to 36.0 and hinge length $(\mathrm{mm}): 0.9$ to 17.5 .

\section{Results and discussion}

Isognomon bicolor (Fig. 1) was observed between three and $22 \mathrm{~m}$ depths on both monobuoys, fouling the structures along with the barnacle Megabalanus coccopoma (Darwin, 1854) and the mussel Perna perna (Linnaeus, 1758). A large population was verified, putatively because the artifacts are offshore, permanently covered and under stable environmental conditions. Usually, $I$. bicolor individuals fixed by byssus were in places where the direct wave impact was absent or minimized by substrate relief (Lopes, 2009).

The $I$. bicolor densities were estimated in 2245 individuals per square meter at $3 \mathrm{~m}$ depth and 1129 individuals per square meter at $22 \mathrm{~m}$ at summer, being similar along of the months (Agostini, 2011). The densities obtained at $3 \mathrm{~m}$ deep support the results recorded in Arraial do Cabo, Rio de Janeiro to this species (2300-2500 ind. $\mathrm{m}^{-2}$ ) (Lopes, 2009). However, in the mollusks inventory done previously by Rios et al. (1979) in the TRANSPETRO monoboys, I. bicolor was not listed. The family Pteriidae Gray, 1847 (1820) has been represented along of Brazil, including the Southern region, with four living genera only: Isognomon Solander, 1786, Pteria Scopoli, 1777, Pinctada Röding, 1798 and Crenatula Lamarck, 1804 (Domaneschi \& Martins, 2002 Coan et al. 2000; Rios, 2009). According to Rios (2009), the Isognomon genus is represented in the Brazilian malacofauna just by I. alatus (Gmelin, 1791) and I. radiatus (Anton, 1838). However, Domaneschi \& Martins (2002) points out the possibility 
that the I. alatus populations of São Sebastião, São Paulo, Brazil, could be I. bicolor.

In the other hand, many researchers recorded I. bicolor in the coast of the states of Santa Catarina, Paraná, São Paulo, Rio de Janeiro, Espírito Santo, Bahia, Pernambuco, Paraíba, Rio Grande do Norte, Ceará and Piauí (Domaneschi \& Martins, 2002; Loebmann et al., 2010, Zamprogno et al., 2010; Rocha-Barreira et al., 2010; Martinez, 2012; Dias et al. 2013; Oliveira \& Creed 2008; Gomes and Silva 2013, and Santos et al., 2015). About Brazilian Southern coast, the most established population of I. bicolor is at Zimbros Beach in Santa Catarina state (Domaneschi \& Martins 2002), approximately $370 \mathrm{Km}$ away straight from Tramandaí Beach in the Rio Grande do Sul. Their works have reported its colonizing in both artificial and natural substrates (rocky shore) and have attributed its adaptive success mainly due to the lack of competitors or specialized predators.

I. bicolor is a native Caribbean mollusk. Artificial materials floating on the sea could be responsible for the $I$. bicolor transport for areas otherwise impossible naturally to the dispersal mechanisms (Thiel \& Gutow, 2005), allowing its contact with new rocky substrates similar to its natural environment in the Caribbean region (Tunnell et al., 2010). Another reason could be the ballast water. Breves et al. (2014) recorded I. bicolor to Uruguay coast $\left(34^{\circ} \mathrm{S}\right)$ and emphasized its extremely rapid and huge expansion in the South Atlantic Ocean. They claim that ship hull fouling or the ballast water was responsible for its introduction. To the Brazilian coast, also, it is believed that this species was accidentally introduced to the ballast water (Breves-Ramos et al., 2009) and ship hulls (Lopes, 2009).

Alien marine species can be introduced into a new geographic area by many ways including ballast water or biofouling. The accumulation of unwanted organisms on hard surfaces occurs on hulls and other submerged parts of vessels (including ducts), shells or carapaces of other species, equipment associated with fishing, mariculture or diving, and even marine debris (GISP, 2008). However, according to Molnar et al. (2008), shipping is the most common pathway (69\%) of species introduction. Maritime transport vessels, through ballast water and fouling on the hulls, are known vectors throughout the history of dispersal of species across oceans (Coutts et al., 2003).

The presence of this mollusk in Tramandaí pipeline monobuoys is probably related to the large influx of Brazilian vessels on site, which can release larvae in the place by encrusted individuals in the hull and by ballast water. The hard substrate closer to the MN-601 and MN-602 monobuoys is the rocky shore in Torres, which is located approximately $100 \mathrm{~km}$ away. However,
Agostini (2011) conducted a species inventory of hard substrates in this place and did not register Isognomon bicolor at any site.

Any artificial substrate into the sea is susceptible to colonization by organisms. Structures, such as piers, ships hulls, and pipeline monobuoys, offer their surfaces for invertebrates' fixation, turning into feeding areas for many other organisms (Bumbeer \& Rocha 2012).

According to López (2003), the snails Stramonita haemastoma (Linnaeus, 1767) and Morula nodulosa (C. B. Adams, 1845) eat I. bicolor. The first snail occurs in both monobuoys (Agostini, 2011), and could be a controlling factor of I. bicolor populations. But, López et al. (2010) reported that this gastropod predator prefers the bivalve Perna perna (Linnaeus, 1758), which also is present in Tramandaí monobuoys (Rios et al. 1979; Agostini, 2011).

\section{Conclusions}

The occurrence of Isognomon bicolor in pipeline monobuoys of Tramandaí Beach represents the first documented record for this species in Rio Grande do Sul state and according to Lopes (2009) this species showed an expressive increase in its density along the Brazilian coast from the mid-1990s. Thus, it is necessary the application of management and control measures, mainly related to disposal of ballast water (Regulation Norman 20 ) and the encrusted community on hulls, to preventing I. bicolor spread. Monobuoys and pipelines should also be considered a vector of bioinvasion from offshore to onshore zone, linking the species brought by ships to the natural substrates such as rocky shore.

\section{Acknowledgements \\ To the company TRANSPETRO (Petrobrás - S.A.) for the collection of charred material from pipeline monobuoys, and to the CECLIMAR for providing the workspace and allowing the deposition of the vouchers in the scientific collection. \\ Funding \\ There is no funding. \\ Availability of data and materials \\ Scientific collection of the Centro de Estudos Costeiros Limnológicos e Marinhos (CECLIMAR) at Federal University of Rio Grande do Sul (UFRGS).}

\section{Authors' contributions}

VOA (design, collection, and data analysis). CPO (design, data analysis and intellectual contribution). Both authors read and approved the final manuscript.

\section{Competing interests}

The authors declare that they have no competing interests.

Consent for publication

Not applicable.

Ethics approval and consent to participate

We declare that none of the authors have any competing interests in the manuscript. 


\section{Author details}

'Universidade Federal do Rio Grande (FURG), Programa de Pós-Graduação em Oceanografia Biológica (PPGOB), Instituto de Oceanografia (IO), Avenida Itália, Km 8, CEP 96203-900 Rio Grande, RS, Brazil. ${ }^{2}$ Universidade Federal do Rio Grande do Sul (UFRGS), Instituto de Biociências, Departamento de Zoologia, Avenida Bento Gonçalves, 9500, CEP 91501-970 Porto Alegre, RS, Brazil.

\section{Received: 3 June 2016 Accepted: 6 June 2016}

Published online: 28 September 2016

\section{References}

Agostini VO. Levantamento dos macroinvertebrados de substratos consolidados naturais e artificiais do litoral norte do Rio Grande do Sul, Brasil e caracterização do processo de bioincrustação em substrato metálico sob condições marinhas costeiras subtropicais. Trabalho de Conclusão de Curso (Bacharelado em Biologia Marinha e Costeira) - Universidade Federal do Rio Grande do Sul, Imbé; 2011. 106 f. doi:10.13140/RG.2.2.30219.49440.

Breves-Ramos A, Junqueira AOR, Lavrado HP, Silva SHG, Ferreira-Silva MAG. Population structure of the invasive bivalve Isognomon bicolor on rocky shores of Rio de Janeiro State (Brazil). J Mar Biol Assoc UK. 2009;90(3):453-9.

Breves A, Scarabino F, Carranza A, Leoni V. First records of the non-native bivalve Isognomon bicolor (C. B. Adams, 1845) rafting to the Uruguayan coast. Check List. 2014:10(3):684-6.

Bumbeer I de A, Rocha RM da. Detection of introduced sessile species on the near shore continental shelf in southern Brazil. Zoologia. 2012;29(2):126-34

Coan EV, Scott PV, Bernard FR. Bivalve seashells of Western North America. Santa Barbara: Santa Barbara Museum of Natural History; 2000. p. 764

Coutts ADM, Moore KM, Hewitt CL. Ships' sea-chests: an overlooked transfer mechanism for non-indigenous marine species? Mar Pollut Bull Oxford. 2003; 46:1504-15.

Dias TLP, Mota ELS, Gondim Al, Oliveira JM, Rabelo EF, de Almeida SM, et al. Isognomon bicolor (C. B. Adams, 1845) (Mollusca: Bivalvia): First record of this invasive species for the States of Paraíba and Alagoas and new records for other localities of Northeastern Brazil. Check List. 2013;9(1):157-61.

Domaneschi O, Martins CM. Isognomon bicolor (C.B. Adams) (Bivalvia, Isognomonidae): primeiro registro para o Brasil, redescrição da espécie e considerações sobre a ocorrência e distribuição de Isognomon na costa brasileira. Rev Bras Zool. 2002;19(2):611-27.

Global Invasive Species Programme (GISP). Marine Biofouling: an assessment of risks and management initiatives. Compiled by Lynn Jackson on behalf of the Global Invasive Species Programme and the UNEP Regional Seas Programme. 2008. p. 68.

Gomes LEdeO, Silva EC. New record of Isognomon bicolor (C. B. Adams, 1845) (Bivalvia, Isognomonidae) to Bahia Litoral North. Pan-Am J Aquat Sci. 2013; 8(4):361-3.

Kado R. Invasion of Japanese shores by the NE Pacific barnacle Balanus gleula and its ecological and biogeographical impact. Mar Ecol Prog Ser. 2003;249: 199-206.

Loebmann D, Mai ACG, Lee JT. The invasion of five alien species in the Delta do Parnaíba Environmental Protection Area, Northeastern Brazil. Rev Biol Trop. 2010;58(3):909-23.

López MS. Efecto de la potencial presa exótica Isognomon bicolor (Adams, 1845) sobre la ecología trófica de Stramonita haemastoma (Kool, 1987) en el intermareal rocoso de Arraial do Cabo, RJ, Brasil. Jaén: MS thesis, Universidad Internacional de Andalucía Sede Antonio Machado de Baeza; 2003.

Lopes MS. Informe sobre as Espécies Exóticas Invasoras Marinhas no Brasil. Ministério do Meio Ambiente; 2009. 441 pp. http://www.mma.gov.br/ estruturas/sbf2008_dcbio/publicacao/147_publicacao07072011012531.pdf.

López MS, Coutinho R, Ferreira CEL, Rilov G. Predator-prey interactions in a bioinvasion scenario: differential predation by native predators on two exotic rocky intertidal bivalves. Mar Ecol Prog Ser. 2010;403:101-12.

Martinez AS. Spatial distribution of the invasive bivalve Isognomon bicolor on rocky shores of Arvoredo Island (Santa Catarina, Brazil). J Mar Biol Assoc UK. 2012;92(3):495-503.

Matthews HR, Kempf M. Moluscos marinhos do norte e nordeste do Brasil. 11 Moluscosdo Arquipélago de Fernando de Noronha (com algumas referências ao Atol das Rocas). Arq Ciênc Mar. 1970;10(1):-153.

Molnar JL, Gamboa RL, Revenga C, Spalding M. Assessing the global threat of invasive species to marine biodiversity. Front Ecol Environ. 2008:6(9):485-492. doi:10.1890/070064
Oliveira AES, Creed JC. Mollusca, Bivalvia, Isognomon bicolor (C. B. Adams 1845): Distribution extension. Check List. 2008:4(4):386-8.

Rios EC. Compendiun of Brazil Sea Shells. 2nd ed. Rio Grande: Evangrap; 2009. p. 663.

Rios EC, Lopes-Pitoni VL, Veintenheimer-Mendes IL. Moluscos marinhos em bóias no Rio Grande do Sul, Brasil. In: Encontro dos Malacologistas brasileiros, 5, 1979. Mossoró. Anais. Porto Alegre: FZBRS; 1979. p. 103-7.

Rocha-Barreira CA, Matthews-Cascon H, Mai ACG. Moluscos. In: Mai ACG, Loebmann D, editors. Guia llustrado: Biodiversidade do Litoral do Piauí. Sorocaba: Paratodos; 2010. p. 62-93.

Santos HF, Borzone CA, Tavares YAG. Distribuição espacial e temporal de Isognomon bicolor (C.B. Adams, 1845) (Bivalvia, Isognomonidae) no litoral paranaense, Brasil. Trabalho Científico;2015. Available at: http://www.mma. gov.br/. Accessed 14 Aug 2015.

Thiel M, Gutow L. The ecology of rafting in the marine environment. II. The rafting organisms and community. Oceanography Mar Biol Ann Rev. 2005;43: 279-419.

Tunnell Jr., JW, Andrews J, Barrera NC, Moretzosohn F. Encyclopedia of Texas: Identification, Ecology, Distribution, and History. Texas A\&M University Press; 2010. 512 pp. https://muse.jhu.edu/book/395.

Zamprogno GC, Fernandes LL, Fernandes FC. Spatial variability in the population of Isognomon bicolor (C.B. Adams, 1845) (Mollusca, Bivalvia) on rocky shores in Espirito Santo, Brazil. Braz J Oceanography. 2010;58(1):23-9.

\section{Submit your next manuscript to BioMed Central and we will help you at every step:}

- We accept pre-submission inquiries

- Our selector tool helps you to find the most relevant journal

- We provide round the clock customer support

- Convenient online submission

- Thorough peer review

- Inclusion in PubMed and all major indexing services

- Maximum visibility for your research

Submit your manuscript at www.biomedcentral.com/submit
) Biomed Central 